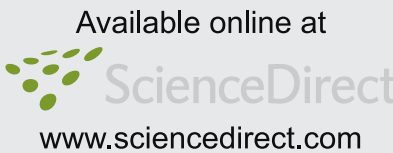

ELSEVIER
Elsevier Masson France

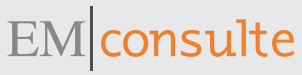

www.em-consulte.com/en

Original article

\title{
Future pest status of an insect pest in museums, Attagenus smirnovi: Distribution and food consumption in relation to climate change
}

\author{
Lise Stengaard Hansen ${ }^{\mathrm{a}, *}$, Monika Åkerlund ${ }^{\mathrm{b}, 1}$, Terje Grøntoft $\mathrm{ft}^{\mathrm{c}, 2}$, Morten Ryhl-Svendsen ${ }^{\mathrm{d}, 3}$, \\ Anne Lisbeth Schmidt ${ }^{\mathrm{d}, 4}$, Jan-Erik Bergh ${ }^{\mathrm{b}, \dagger}$, Karl-Martin Vagn Jensen ${ }^{\mathrm{e}, 5}$ \\ a Aarhus University, Faculty of Science and Technology, Department of Agroecology, Research Center Flakkebjerg, 4200 Slagelse, Denmark \\ b Swedish Museum of Natural History, PRE-MAL, PO Box 50007, Stockholm, Sweden \\ c Norwegian Institute for Air Research (NILU), PO Box 100, 2027 Kjeller, Norway \\ ${ }^{\mathrm{d}}$ National Museum of Denmark, Department of Conservation, IC Modewegsvej, Brede, DK-2800 Kgs, Lyngby, Denmark \\ e Aarhus University, Faculty of Science and Technology, Department of Agroecology, Research Center Flakkebjerg, DK-4200 Slagelse, Denmark
}

\section{A R T I C L E I N F O}

\section{Article history:}

Received 16 February 2011

Accepted 2 May 2011

Available online 22 June 2011

\section{Keywords:}

Attagenus smirnovi

Consumption

Temperature

Climate change

Museum pests

\begin{abstract}
A B S T R A C T
The brown carpet beetle Attagenus smirnovi, Zhantiev 1973 (Coleoptera: Dermestidae) is an important pest of objects of organic origin in museums of cultural and natural history in Europe. Future climate changes are expected to lead to increasing temperatures, which will affect the pest status of this species. In the present study a laboratory investigation was conducted to elucidate the effect of temperature and humidity on the amounts of organic material consumed by larvae of A. smirnovi. In the case of new and old skin, consumption was approximately twice as high at $28^{\circ} \mathrm{C}$ compared to $20^{\circ} \mathrm{C}$. Wool was consumed in the greatest amounts: $169 \mathrm{mg}$ of wool was consumed in three months by $30 \mathrm{~A}$. smirnovi larvae. The expected future climate changes in Scandinavia are assumed to lead to higher temperatures in museums and stores where climate is not regulated. Updated data on the present distribution of A. smirnovi in Europe show that it is widespread and common, also in regions with a climate that does not support its survival out of doors. Thus, dispersal of this pest probably only rarely occurs by flight, but usually with human activity. Due to the widespread distribution of A. smirnovi, it is likely that damages in museums and collections in Scandinavia due to this pest will increase as climate changes come into effect.
\end{abstract}

(C) 2011 Elsevier Masson SAS. All rights reserved.

\section{Research aims}

Insects consume a wide range of materials found in museums of cultural and natural history, i.e. organic materials such as wool, woollen cloth, silk, feather, leather and paper. Temperature is an important factor in insect biology; within certain limits their activity and reproduction increase with increasing temperatures. As climate changes are expected to lead to increasing temperatures, this may lead to an increase in the development of damages

\footnotetext{
* Corresponding author. Tel.: +458 9993565.

E-mail addresses: LiseS.Hansen@agrsci.dk (L. Stengaard Hansen), monika.akerlund@nrm.se (M. Åkerlund),teg@nilu.no

(T. Grøntoft), morten.ryhl.svendsen@natmus.dk (M. Ryhl-Svendsen), anne.lisbeth.schmidt@natmus.dk (A.L. Schmidt), Karl-MartinV.Jensen@agrsci.dk (K.-M. Vagn Jensen).

1 Tel. +46 (0) 851954201 .

2 Tel. +4763898023 .

${ }^{3}$ Tel. +4533473517 .

4 Tel. +4533473537 .

5 Tel. +4589993701 .

$\dagger$ Deceased June 2009.
}

due to insect pests in museums. The present study focused on the brown carpet beetle Attagenus smirnovi, an important pest of organic materials in museums of cultural and natural history in Northern Europe. New information was collected on its distribution in Europe and an investigation was conducted to elucidate how the consumption of organic materials by A. smirnovi is affected by different levels of temperature and humidity, and, as a consequence, how the risk for damage in museums due to A.smirnovi will be affected by expected future climate change.

\section{Introduction}

The brown carpet beetle A. smirnovi, Zhantiev 1973 (Coleoptera: Dermestidae) and other dermestids are important insect pests of objects of organic origin in museums of cultural and natural history in Europe $[1,2]$. Many aspects of insect biology are positively correlated with temperature, e.g. development rate, reproduction, and consumption. A. smirnovi is a species that consumes relatively large amounts of its diet, maybe due to the poor nutritional value of the materials. Small increases in temperature could therefore lead to great increases in damage rates. Future climate changes in the Nordic countries could provide better conditions for A. smirnovi 
and increase the amount of damage caused by this pest to organic cultural heritage objects.

As climate changes are expected to lead to increasing temperatures [3], the present study was carried out to investigate how this will affect the development of damage due to A. smirnovi. Models of climate changes for Scandinavia were analysed in an attempt to predict which consequences this will have on both the general climate and the indoor climate in museums and collections, starting with already known data from museums. These issues are discussed in relation to the results of a laboratory investigation of the effect of temperature on the consumption of different materials caused by this pest. Finally, updated information was collected on the distribution of A.smirnovi in Europe, i.e. first reports and frequency in different countries, which may be used as baseline data on the dispersal of A. smirnovi in European museums.

\section{Biology, an updated review}

A. smirnovi is a dermestid beetle with origins in tropical Africa [4]. It is spreading as an indoor insect in Europe [5]. In the first reports from Europe in the 1960s it was identified as A. alfieri, A. longicornis, etc., but after 1974, it has been identified as A. smirnovi [6-8]. Several species of dermestids cause serious damage to objects in museums made of organic materials such as wool, woollen cloth, silk, feather, leather and paper [1]. A. smirnovi is the pest species most commonly found in exhibits and stores of the National Museum of Denmark.

A.smirnovi has one to two generations per year in indoor premises. Adult beetles are described as good flyers and are attracted to lights. They are often found in numbers in light fittings [9] and have been observed flying during the months of April to August $[10,11]$. Under optimal conditions $\left(24^{\circ} \mathrm{C}\right.$ and relative humidity [RH] 70-80\%), the adult lives about 20 days. Each female produces 30 to 70 eggs; the incubation time for eggs is 10-14 days [12].

The upper temperature limit for survival of the larvae is $34^{\circ} \mathrm{C}$, regardless of humidity. Below $55 \% \mathrm{RH}$, temperature seems to be the most important factor for survival. At $20^{\circ} \mathrm{C}$ and $65 \%$ a bimodal distribution is seen in the length of the larval period: some pupate after 4-5 months and others after 9-12 months [13]. The duration of development is partly dependent on the time of year. The pupal stage lasts $8-13$ days [12].

The diet of A. smirnovi larvae includes materials containing both animal protein and starch such as those found in organic debris in voids in constructions. Once established here they can be very difficult to eradicate [14]. Control of this pest in museum artefacts is often obtained by freeze disinfection. A recent study showed that $100 \%$ mortality of the larvae was obtained after exposure to $-14.4^{\circ} \mathrm{C}$ for 24 hours, and $98 \%$ mortality was obtained at $-11.8^{\circ} \mathrm{C}$ for 24 hours [15].

\section{Consumption in relation to temperature and relative humidity}

A study was carried out to describe the effect of temperature and humidity on the amounts of four different materials consumed by A. smirnovi larvae.

\subsection{Materials and methods}

The investigation was conducted at combinations of three temperatures $\left(20,24\right.$ and $28^{\circ} \mathrm{C}$ ) and two levels of relative humidity (50 and $75 \% \mathrm{RH})$.

The materials used in the study were:
1. new skin: seal, less than 1 year old, de-haired, without the outer layer of the skin (epidermis) (Kittat, Nuuk, Greenland),

2. old skin: seal, more than 60 years old, de-haired, with epidermis (material collection, Dept. of Conservation, National Museum of Denmark),

3. woollen material: white sheep, washed once, untreated; sample analysed prior to use revealed no pesticide residues (Historicum, Haderslev, Denmark),

4. feathers: white, from gull (Larus sp.) (Natural History Museum of Denmark).

The materials were acclimated for minimum three days at the specific climatic conditions under which they were to be used. Suitable amounts of one of the materials were weighed (precision: $1 \mathrm{mg})$ and placed in plastic containers $(6 \times 4 \times 2 \mathrm{~cm}$ with a hole covered with fine wire mesh in the lid). Test specimens of $A$. smirnovi were collected from a colony that had been reared on at diet of crushed dog biscuits with $5 \%$ dry yeast, $1 \%$ glycerine and $1 \%$ tap water, in a controlled climate chamber $\left(25^{\circ} \mathrm{C}, 65 \% \mathrm{RH}\right)$ at Aarhus University, Dept. of Agroecology for less than 5 years. Thirty larvae of A. smirnovi were transferred to each of the containers by the means of a soft brush. The average weight of the larvae was 5-6 mg, i.e. medium size, chosen to ensure that they would remain in the larval stage during the three months of the trial. Three replicates of each material at each combination of temperature and RH were used, a total of 72 units. For each climate combination three units with the materials alone were used to check changes in weight. The units were incubated under the experimental climate conditions for 3 months (92 days). The weight of the materials and the number of surviving larvae were then registered.

The weight loss of the material in each unit was calculated and corrected for changes in weight registered in the materials in units without larvae, i.e. changes resulting from possible fluctuations in humidity. A test for variance homogeneity revealed no significant differences. All data were then tested by means of ANOVA, and significant differences between the consumption of different materials as well as the survival of the larvae in relation to temperature and RH were identified by the means of Tukey's Studentized Range Test $(p=0.05)[16]$.

\subsection{Results}

The results are shown in Tables 1 and 2 and Fig. 1.

\subsubsection{Survival}

The survival of A.smirnovi larvae was significantly lower on wool than on skin in all cases, and in some cases lower on feathers (Table 1). The survival on wool was as low as $58 \%$ after three months $\left(28^{\circ} \mathrm{C} / 50 \% \mathrm{RH}\right.$ and $\left.24^{\circ} \mathrm{C} / 75 \% \mathrm{RH}\right)$. On both types of skin and on feathers the survival of the larvae was generally above $93 \%$.

\subsubsection{Consumption}

No differences were found in the consumption of the different materials in relation to relative humidity, except in one case (feathers) where significantly more was consumed at $75 \% \mathrm{RH}(p<0.05)$.

The consumption of wool and new skin increased with increasing temperature at both humidity regimes and old skin at high $\mathrm{RH}$ (Table 2). On these materials, the consumption was significantly higher at $28^{\circ} \mathrm{C}$ than at $20^{\circ} \mathrm{C}$ and increased with more than $60 \%$. In the case of both new and old skin, the consumption was approximately twice as high at high temperature compared to low temperature (the results for old skin at $20^{\circ} \mathrm{C} / 50 \% \mathrm{RH}$ are ignored due to an extreme standard deviation). The greatest amount consumed by the initial 30 larvae was $169 \mathrm{mg}$ of wool over the test period of three months and the smallest amount was $30 \mathrm{mg}$ of old 
Table 1

Survival of 30 Attagenus smirnovi larvae $( \pm$ SD) after 3 months on different materials.

\begin{tabular}{|c|c|c|c|c|c|c|}
\hline \multirow[t]{2}{*}{ Live larvae } & \multicolumn{3}{|l|}{$50 \% \mathrm{RH}$} & \multicolumn{3}{|l|}{$75 \% \mathrm{RH}$} \\
\hline & $20^{\circ} \mathrm{C}$ & $24^{\circ} \mathrm{C}$ & $28^{\circ} \mathrm{C}$ & $20^{\circ} \mathrm{C}$ & $24^{\circ} \mathrm{C}$ & $28^{\circ} \mathrm{C}$ \\
\hline New skin & $29.3 \pm 0.6^{a}$ & $29.0 \pm 1.0^{\mathrm{a}}$ & $28.0 \pm 2.6^{a}$ & $28.7 \pm 1.5^{a}$ & $26.3 \pm 5.6^{a}$ & $29.7 \pm 0.6^{\mathrm{a}}$ \\
\hline Old skin & $29.7 \pm 0.8^{a}$ & $29.0 \pm 1.0^{\mathrm{a}}$ & $28.0 \pm 1.7^{\mathrm{a}}$ & $28.0 \pm 1.7^{\mathrm{a}}$ & $30.3 \pm 0.6^{a, c}$ & $28.0 \pm 1.7^{\mathrm{a}}$ \\
\hline Wool & $25.0 \pm 2.0^{\mathrm{b}}$ & $23.7 \pm 2.5^{\mathrm{b}}$ & $17.3 \pm 6.1^{\mathrm{b}}$ & $23.3 \pm 2.5^{\mathrm{b}}$ & $17.3 \pm 2.5^{\mathrm{b}}$ & $19.3 \pm 3.2^{\mathrm{b}}$ \\
\hline Feathers & $28.3 \pm 0.6^{a}$ & $27.3 \pm 1.5^{\mathrm{a}, \mathrm{b}}$ & $26.0 \pm 3.0^{\mathrm{a}, \mathrm{b}}$ & $28.0 \pm 1.0^{\mathrm{a}}$ & $28.0 \pm 1.0^{\mathrm{a}}$ & $27.0 \pm 2.6^{a}$ \\
\hline
\end{tabular}

${ }^{\mathrm{a}, \mathrm{b}}$ Averages within the same columns followed by the same letters are not significantly different.

c Thirty-one larvae added initially.

Table 2

Amounts consumed (mg, \pm SD) of different materials by 30 larvae of Attagenus smirnovi over 3 months at different combinations of temperature and RH.

\begin{tabular}{|c|c|c|c|c|c|c|c|c|}
\hline \multirow{2}{*}{$\begin{array}{l}\text { mg } \\
\text { Temp. }\left({ }^{\circ} \mathrm{C}\right)\end{array}$} & \multicolumn{4}{|l|}{$50 \% \mathrm{RH}$} & \multicolumn{4}{|l|}{$75 \%$ RH } \\
\hline & New skin & Old skin & Wool & Feathers & New skin & Old skin & Wool & Feathers \\
\hline 20 & $57.3 \pm 16.0^{\mathrm{a}}$ & $82.7 \pm 63.1^{\mathrm{a}}$ & $103.3 \pm 11.0^{\mathrm{a}}$ & $71.7 \pm 5.5^{\mathrm{a}}$ & $52.3 \pm 6.8^{a}$ & $30.3 \pm 3.8^{\mathrm{a}}$ & $103.0 \pm 15.4^{\mathrm{a}}$ & $73.3 \pm 7.6^{\mathrm{a}}$ \\
\hline 24 & $89.7 \pm 16.3^{a, b}$ & $46.7 \pm 15.3^{\mathrm{a}}$ & $150.0 \pm 20.0^{\mathrm{a}, \mathrm{b}}$ & $89.3 \pm 13.5^{\mathrm{a}}$ & $77.3 \pm 24.7^{\mathrm{a}, \mathrm{b}}$ & $59.0 \pm 17.6^{\mathrm{a}, \mathrm{b}}$ & $123.3 \pm 15.3^{a}$ & $75.7 \pm 6.7^{\mathrm{a}}$ \\
\hline 28 & $94.0 \pm 5.0^{\mathrm{b}}$ & $92.3 \pm 16.2^{\mathrm{a}}$ & $164.3 \pm 35.2^{\mathrm{b}}$ & $56.0 \pm 18.2^{\mathrm{a}}$ & $101.3 \pm 6.4^{\mathrm{b}}$ & $70.7 \pm 17.5^{\mathrm{b}}$ & $169.0 \pm 17.3^{b}$ & $89.7 \pm 9.3^{\mathrm{a}}$ \\
\hline
\end{tabular}

$\mathrm{a,b}$ Averages within the same columns followed by the same letters are not significantly different.

skin. No differences could be determined in the consumption of feathers at both RH due to large variation among replicates.

A comparison of the amounts consumed of the different materials is shown in Fig. 1. No differences were found between the materials consumed at $20^{\circ} \mathrm{C} / 50 \% \mathrm{RH}$, but at all other conditions significantly more wool was consumed when compared with skin and feathers. The consumption of old skin was lowest in all cases except one, but differences were not always significant.

\subsection{Consumption, discussion}

Temperature greatly affected the consumption rate, in some cases with increases of $230 \%$ if temperature changed from 20 to $28^{\circ} \mathrm{C}$. Wool was consumed in the greatest amounts. In the situation with the highest consumption, $0.06 \mathrm{mg}$ of wool was consumed per larva per day. Over one year, it can amount to $22 \mathrm{mg}$ wool per larva or a hole of approximately $1 \mathrm{~cm}^{2}$ in light woollen fabric. Survival was poor on wool, with only $57 \%$ surviving after three months. This means that the surviving larvae each must have consumed more than the average of $0.06 \mathrm{mg}$.

A few other studies have found an effect of temperature on food consumption rates, mostly using plant pests $[17,18]$, but with much smaller differences between low and high temperatures than the ones found in the present investigations. The effects of an increase in the ambient temperature are thus greater in A.smirnovi than it is with plant pests. This difference can be attributed to the poor nutritional value of wool and skin compared with plants.

\section{Indoor climate conditions that support A. smirnovi}

Data from the pest database at the National Museum of Denmark, Copenhagen, were used to describe the climate conditions

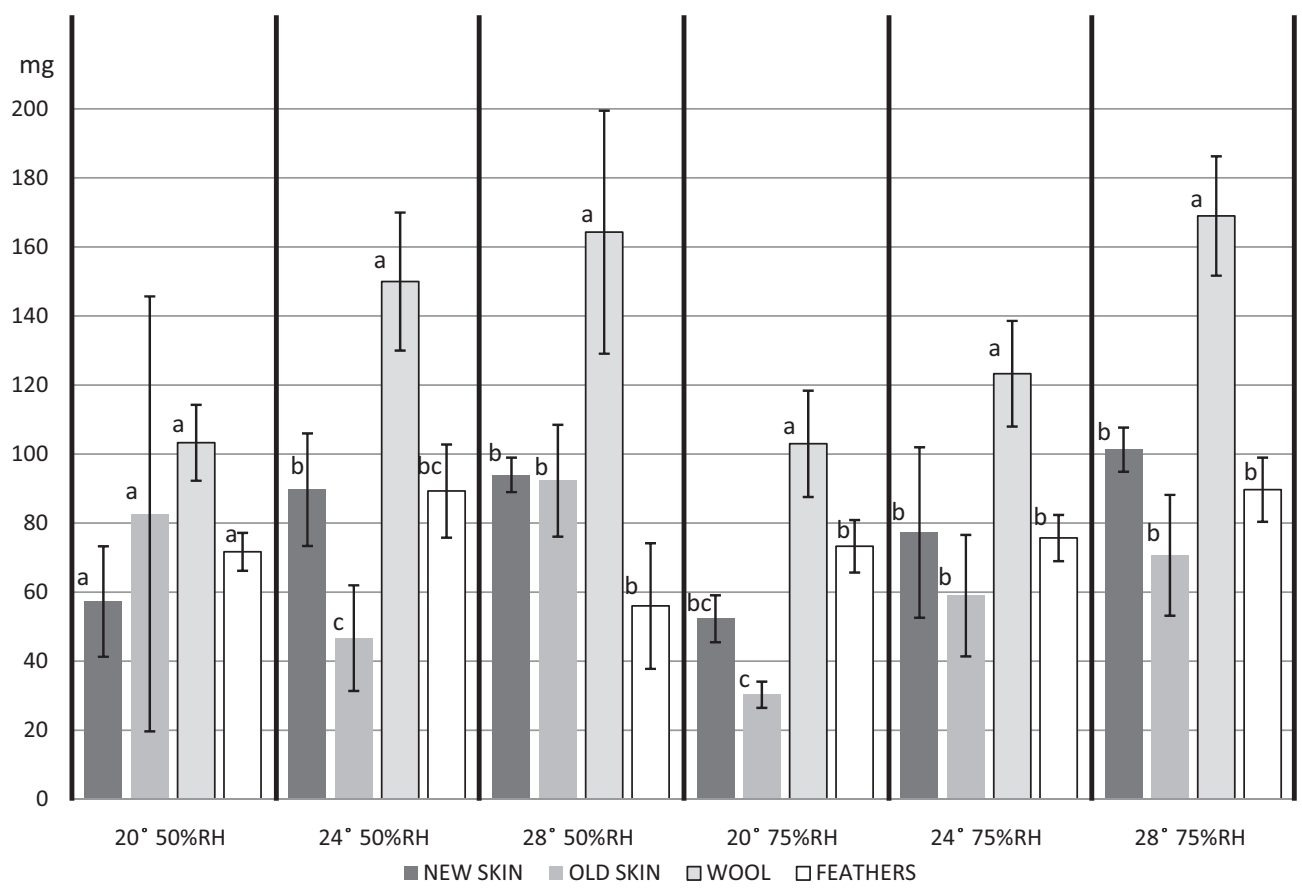

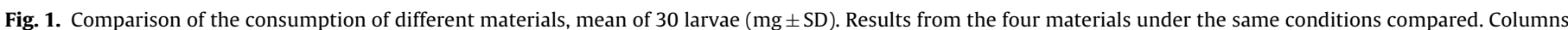
in groups of four marked with the same letter are not significantly different $(p=0.05)$. 


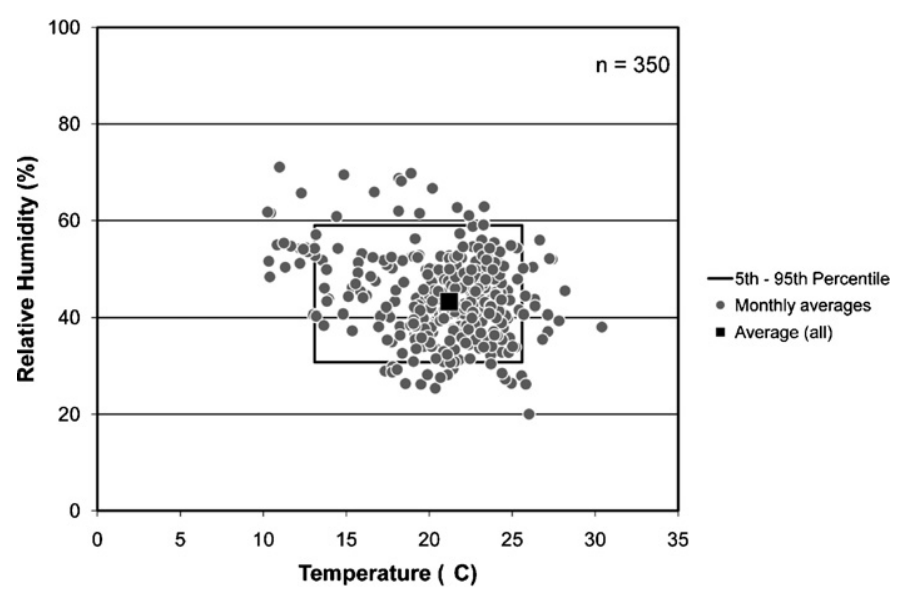

Fig. 2. Indoor climate conditions that support Attagenus smirnovi in the National Museum of Denmark. Monthly averages of temperature and relative humidity (over a minimum of 12 months) in 22 locations in which $A$. smirnovi has been observed.

that support A. smirnovi. Observations of A. smirnovi in the museum premises from the database from 2001 to 2009 were combined with indoor climate data from the same locations to describe the climate where A. smirnovi was observed and compared with the climate in locations where A. smirnovi had not been observed.

\subsection{Methods}

Insects are monitored using sticky traps or by inspection of premises. Reports in the database with species names are entered by the museum's inspection staff. Regular inspection rounds are conducted twice yearly. If insects are encountered at other times the finding is also entered into the database. Findings are regularly sent to entomologists at Aarhus University, Dept. of Agroecology, for confirmation of the identification. All observations are combined with date, location and stage of insect. Observations were related to a location or climate zone defined as one or several uniform rooms, e.g. adjacent rooms that are supplied by the same ventilation system. Climate data were collected by permanently installed sensors (building management system monitoring of temperature and relative humidity) or by data loggers (Preservation Environmental Monitor ${ }^{\mathrm{TM}}$ for temperature and RH, IPI Rochester, USA). Recordings were made at 30 or 60 min intervals.

\subsection{Results}

During the eight years' study period $22 \%$ of all insects observed in the National Museum were A. smirnovi. Specimens of A. smirnovi were reported 153 times in 22 locations, where one report may cover the occurrence of one or several individual A. smirnovi at the time of observation.

The indoor climate from the 22 locations where A. smirnovi was observed is shown in Fig. 2 as monthly averages of temperature and $\mathrm{RH}$. The mean climate for all sites $\left( \pm \mathrm{SD}\right.$ ) was $21.2 \pm 3.7^{\circ} \mathrm{C}$ and $43 \pm 8.8 \% \mathrm{RH}$. Climate extremes with minimum and maximum temperatures of 4.5 and $41.7^{\circ} \mathrm{C}$, and minimum and maximum $\mathrm{RH}$ of 10 and $80 \%$, respectively, were recorded at single locations for short periods of time (few hours), but these extremes were not included in the analysis. The climate conditions shown in Fig. 2 represent at least one year of continuous climate measurements from each location, and for nine locations from two years data or more. In each instance, the chosen climate data are from the year of observation(s). In total, Fig. 2 is constructed from 350 single monthly averages of temperature and relative humidity measured in 22 indoor locations. The majority of data points (between the 5 th and 95th percentiles) are expected to represent an indoor climate in which A.smirnovi has been identified numerous times. Although the majority of the pest observations were of larvae alone (61\% larvae only, $24 \%$ adults only, $15 \%$ larvae and adults in the same trap), A. smirnovi was found both as larvae and adults in all locations. Temperatures ranged from 13.1 to $25.6^{\circ} \mathrm{C}$ and the relative humidity from 31 to $59 \%$. A. smirnovi may live well outside the climate encased by this data set; however, we do not have any observations to support this. Data points outside the 5th and 95th percentiles were removed from the results, in order to avoid the inclusion of possible outlying short term climate extremes, e.g. due to a defect heating system. It should be noted, however, that observations are not evenly distributed; the main weight of the observations lie towards the higher temperatures (about $18-25^{\circ} \mathrm{C}$ ) regardless of $\mathrm{RH}$.

In another four locations, in which A.smirnovi was never observed, the mean temperature was $14.9^{\circ} \mathrm{C}$ and the mean relative humidity $58 \%$. However, although the climate in these four locations appears to be cooler and more humid than the climate zone of Fig. 2, the two groups of observations (locations with or without $A$. smirnovi) cannot be claimed to be significantly different. There may be other reasons for the absence of A.smirnovi in the four locations, i.e. that $A$. smirnovi was simply never introduced to the sites.

\section{Changes in climate factors affecting insects}

Future climate changes with higher outdoor temperature and humidity will lead to increases in indoor locations where the climate more or less follows the outdoor climate, and this will most probably affect the consumption and reproduction rates of indoor pests such as A.smirnovi. The ability of A. smirnovi to disperse by flying outdoors may also be affected by these factors and possibly the number of sun shine hours (shown for other insect species [19]). An analysis of the future development of temperature and sun shine hours in Scandinavia due to expected climate changes was conducted in order to elucidate how this will affect $A$. smirnovi.

\subsection{Methods}

The analysis was based on data available from climate modelling performed by the Rossby Centre ${ }^{7}$ [20]. Variation in available predictions is partly due to different models and scenarios used (IPCC A2 and B2 [21]). The climate during the period 1961-1990 was used as a reference.

\subsection{Results}

Modelling results for changes in monthly mean temperature and monthly mean number of sun hours are shown in Figs. 3 and 4.

The temperature modelling generally predicts increasing average temperatures over the next 100 years. The largest changes in the period 2071-2100 are expected in the winter months and in the north $\left(+6-7^{\circ} \mathrm{C}\right)$. Average summer temperatures are predicted to increase by 1 to $2^{\circ} \mathrm{C}$ in southern Scandinavia for the period 2011-2040, rising to an increase of 2 to $4{ }^{\circ} \mathrm{C}$ at the end of the century (Fig. 3). The climate modelling predicts more sun hours during this century in southern Scandinavia in the late summer, July-September, but a decrease in the number of sun hours for the

\footnotetext{
7 The available modelling results were obtained with the Rosby Centre regional Atmosphere model, RCA3 and Rosby Centre regional Atmosphere and Ocean model, RCAO, and ERA 40 observational data for the period 1961-1990 as driver for the ECHAM4 and HADAM3H models and using the IPCC A2 and B2 scenarios (IPCC, 2000) for future periods.
} 

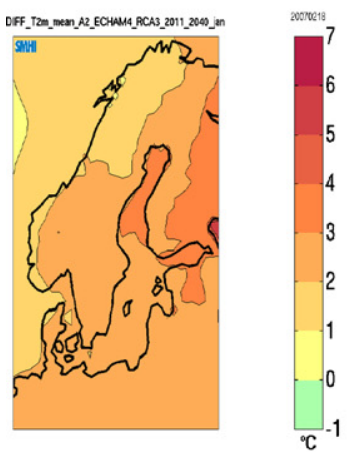

January
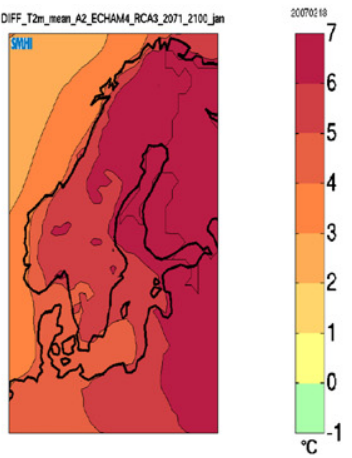

$2071-2100$

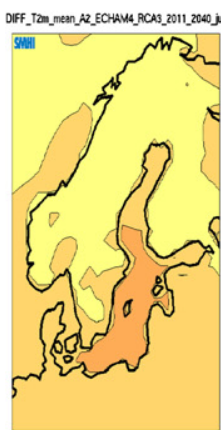

2011-2040
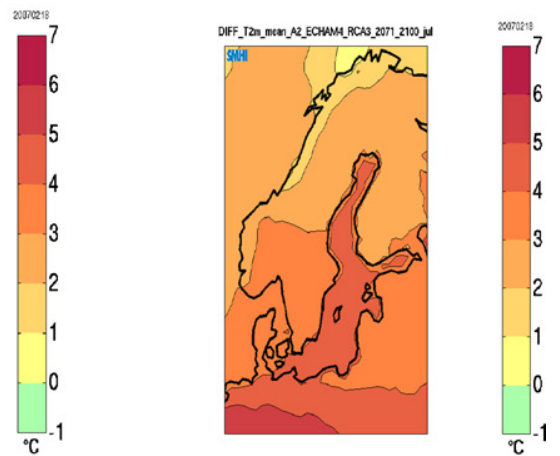

July

Fig. 3. Predicted changes in monthly mean temperatures $\left({ }^{\circ} \mathrm{C}\right) 2 \mathrm{~m}$ above ground during two future periods. The IPCC A2 scenario was used.

rest of the year in southern Scandinavia and for all the year for the rest of Scandinavia (Fig. 4).

Over the next 100 years the annual number of days with a maximum temperature above $20^{\circ} \mathrm{C}$ is predicted to increase in the most southern parts of Scandinavia with up to 35-50 days, compared to about 30 days today, with gradually less change towards the north and west from a lower start level (<10 days). The annual number of degree-days above $20^{\circ} \mathrm{C}$ (sum of the daily average degrees above $20^{\circ} \mathrm{C}$ ) is predicted to increase with $0-30 \%$ in this century for most of the Nordic area, and with $30-120 \%$ in the south eastern Nordic area; eastern Denmark, south eastern Sweden and southern Finland, when the RCAO model (Rosby Centre) is applied. A similar pattern is seen for the annual increase in "tropical nights" with minimum temperatures higher than $20^{\circ} \mathrm{C}$. The maximum predicted increase is between 30-60 days, with the largest increase for the eastern Danish islands, the Götaland-Värmland area in central southern Sweden (local hot spot) and somewhat less pronounced in southeastern Finland.

\section{Geographical distribution of $A$. smirnovi in Europe}

Information on findings of A. smirnovi in all of Europe was collected through literature studies, inquiries via discussion lists on the Internet, and personal contacts. Six hundred and seventy-nine findings or observations from 16 countries were reported. The data is shown in Fig. 5. No findings were reported from the Mediterranean area and only a few were from south of the Alps.

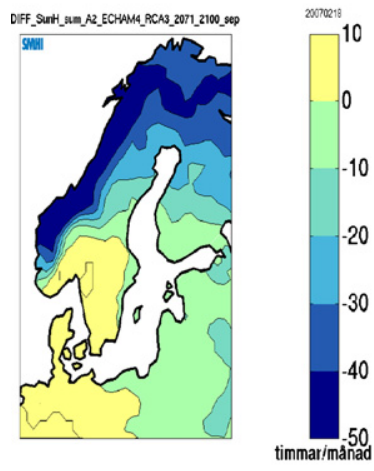

September 2071-2100

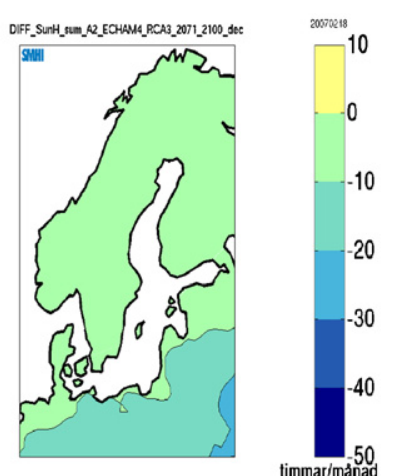

December 2071-2100
Fig. 4. Predicted changes in monthly number of sun hours until the noted future period for two months. The IPCC A2 scenario was used.

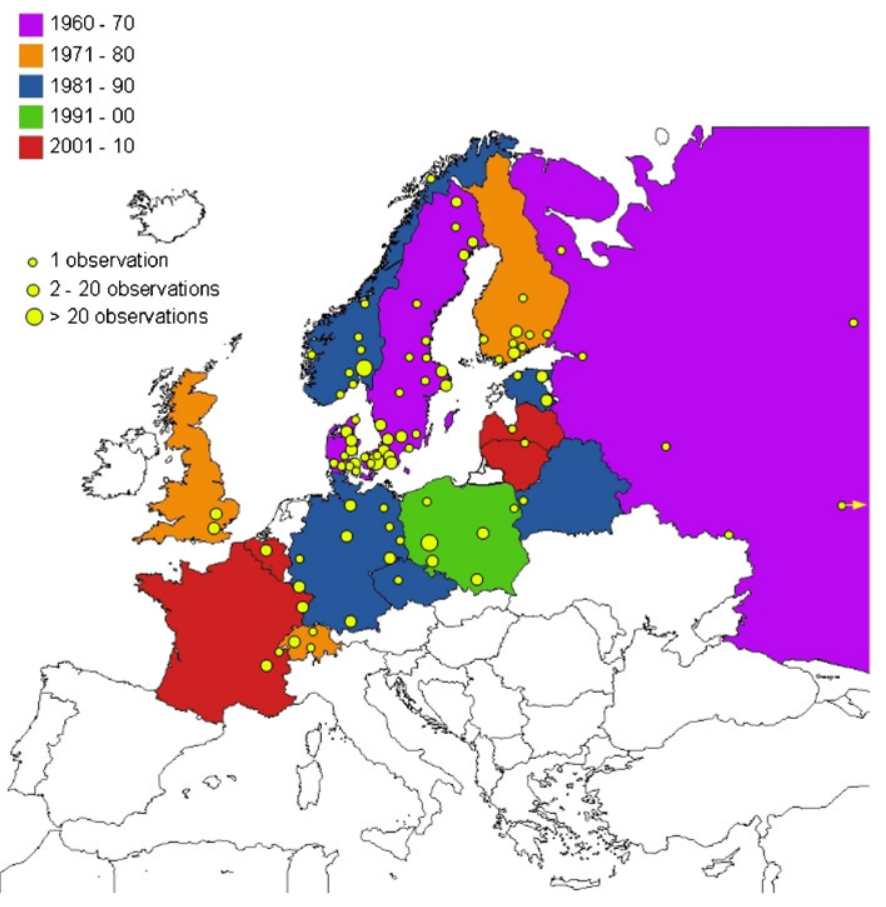

Fig. 5. Map of Europe showing observations of Attagenus smirnovi, based on $[1,5,7,8,11,22-29]$ and personal communication with A.Barševskis, O.Biström, J. Busch, T.Clayhills, P.Christensson, J.Ferrer, B.Gustavsson, A. Hermann, C. Huber, K.Johnson, J.Jungerstam, M. Lillig, J.Lønnve, A. Nilsson, A. Nivart, P.Ottesen, D. Pinniger, I.Süda, S. Roth, I.Rutanen, M.Veseth, AU/Danish Pest Infestation Laboratory database, www.fugleognatur.dk (accessed April 2009), http://www.gbif.se/search/attagenus\%20smirnovi/0/(accessed May 2009). Outdoor findings were reported from Germany [29], Switzerland [11], Belgium [28] and Estonia (Süda, pers. com.).

The colour of the country indicates the time of first observation.

\section{Discussion and conclusion}

A.smirnovi was first observed in Russia in 1961 and has since then been observed in many European countries north of the Alps. In the National Museum of Denmark A.smirnovi is the insect pest most commonly found in the monitoring procedures. The described indoor climate where it was found is largely representative for common indoor environments of museum exhibition and storage areas. It is well known that temperature is an important factor for the biology of insects, as was shown, in this study, to be the case for A. smirnovi. The investigation of the consumption rates for 
A. smirnovi showed that the amount of organic materials (wool and skin) consumed by the larvae greatly increased when the temperature changed from 20 to $28^{\circ} \mathrm{C}$; in the case of new and old skin about twice as much was consumed at high temperature compared to the amount consumed at low temperature.

Results from modelling of the future climate in the Nordic area for the next 100 years show that the area with climate conditions that may support development and possibly also dispersal of this pest will increase during the next 100 years. Increasing numbers of sun hours and hot days in the summers and late summers in south/south eastern Scandinavia in the future may make dispersal of A.smirnovi by flying more likely. However, A. smirnovi has also been observed in regions with a climate that does not support its reproduction and development out of doors (e.g., northern Scandinavia). Thus, the dispersal of this pest does not seem to depend on the outdoors climate alone. In these cases, the plausible explanation for the presence of the pest is that it is spread by humans, maybe with artefacts that are exchanged among museums. The reproduction and consumption rates of A. smirnovi in indoor locations that are affected by the outdoor climate are expected to increase all over the Nordic countries due to higher temperatures during the coming 100 years, but to the greatest degree in the northern areas of Scandinavia, where winter temperatures may increase with up to $7^{\circ} \mathrm{C}$. The increasing summer temperatures in the southern parts of Scandinavia are especially problematic as they may lead to general temperatures above $20^{\circ} \mathrm{C}$ which result in increased consumption rates and development of this pest, possibly also to an increase in the number of insect generations per year. It is foreseen that energy savings in museums and collections will lead to reductions in summer cooling, which will result in higher indoor temperatures and thus improved conditions for A. smirnovi in museums. Thus, global warming may greatly increase the development of damages due to A. smirnovi, and most certainly also its reproduction and possibly its dispersal to new locations, thus enhancing the threat to our cultural heritage. A. smirnovi is one of several insect species that might have an increasing impact as pests of cultural heritage due to climate changes in the Nordic countries and probably all over Europe. This emphasizes the importance of having a well developed IPM (Integrated Pest Management) strategy [1] for all collections.

\section{Acknowledgements}

Thanks are due to Bodil M.Pedersen and Lars Damberg for technical assistance and to two anonymous reviewers for valuable comments. This study was supported financially by the Nordic Cultural Fund, Aarhus University, the National Museum of Denmark, the Norwegian Institute for Air Research, the Norwegian project; Climate Adaptation in Norwegian Municipalities (http://www.klimakommune.no) and the Swedish Museum of Natural History.

\section{References}

[1] D.P. Pinniger, Pest management in museums archives and historic houses, Archetype Publications Ltd, London, U.K, 2001.

[2] M. Åkerlund, Ängrar-finn dom? (Dermestids-do they exist?) [in Swedish], Svenska Museiföreningen, Uppsala, Sweden, 1991.
[3] S. Solomon, D. Qin, M. Manning, Z. Chen, M. Marquis, K.B. Averyt, M. Tignor, H.L. Miller (Eds.), Contribution of Working Group I to the Fourth Assessment Report of the Intergovernmental Panel on Climate Change, Cambridge University Press, Cambridge, United Kingdom and New York, NY, USA, 2007 (accessed Jan 2011) http://www.ipcc.ch/publications_and_data/ar4/wg1/en/contents.html.

[4] R.D. Zhantiev, New and little known Dermestids (Coleoptera) in the fauna of the USSR [In Russian], Zool. Zhurn. 52 (1973) 282-284.

[5] R. Ruta, S. Konwerski, M. Kadej, A. Herrmann, A. Lasoń, Three species of dermestid beetles (Coleoptera: Dermestidae) new to the Polish fauna with remarks on dermestids introduced to Poland, Pol. Pismo Entomol. 73 (2004) 307-314.

[6] K. Arevad, Attagenus smirnovi Zhantiev (Coleoptera, Demestidae): optræden i Danmark (Attagenus smirnovi Zhantiev (Coleoptera, Demestidae): occurence in Denmark) [In Danish], Ent. Meddr. 43 (1975) 172-176.

[7] E.R. Peacock, Attagenus smirnovi Zhantiev (Coleoptera: Dermestidae) a species new to Britain, with keys to the adults and larvae of British Attagenus, Entomol. Gaz. 30 (1979) 131-136.

[8] T. Hagström, Den bruna pälsängerns rätta identitet (The true identity of the brown fur beetle) [In Swedish], Fauna och Flora 76 (1981) 141-142.

[9] D.B. Pinniger, Watch out! Vodka beetles about, Pest Magazine (2010), September/October 2010.

[10] R.D. Zhantiev, The Dermestidae of the USSR [In Russian], Izd. Moskovsk. Univ, Moskva, 1976

[11] S. Kiener, Bemerkenswerte Käfernachweise aus der Scweiz (Coleoptera) (Remarkable records of beetles in Switzerland (Coleoptera)) [In German], Mitt. Schweiz. Entomol. Ges. 68 (1995) 55-68.

[12] Z.P. Dvoriashina, The Smirnovi Beetle as a Pest in Libraries, Restaurator 9 (1988) 63-81.

[13] G.E. Woodroffe, M. Burn, Attagenus sp.nr cyphonoides, Pest Infest. Res. (1964) 11-12.

[14] H. Kingsley, D.P. Pinniger, Trapping used in a large store to target cleaning and treatment, in: H. Kingsley, D.P. Kingsley, A. Xavier-Rowe, P. Winsor (Eds.), Integrated Pest Management for Collections, Proceedings of 2001: A Pest Odyssey, James and James, London, 2001, pp. 51-56.

[15] J.-E. Bergh, K.-M.V. Jensen, M. Åkerlund, L.S. Hansen, M. Andrén, A contribution to standards for freezing as a pest control method for museums, Collection Forum 21 (2006) 117-125.

[16] SAS 9.1, SAS Institute Inc., Cary, NC, USA. 2002-03.

[17] J.M. Scriber, R.C. Lederhouse, Temperature as a factor in the development and feeding ecology of tiger swallowtail caterpillars, Papilio glaucus (Lepidoptera), Oikos 40 (1983) 95-102.

[18] S.E. Reynolds, S.F. Nottingham, Effects of temperature on growth and efficiency of food utilization in fifth-instar caterpillars of the tobacco hornworm Manduca sexta, J Ins Physiol 31 (1985) 129-134.

[19] T. Lewis, L.R. Taylor, Diurnal periodicity of flight by insects, Trans. Royal Entomol. Soc. London 116 (1965) 393-435.

[20] http://www.smhi.se/, 2009.

[21] N. Nakicenovic, J. Alcamo, G. Davis, H.J.M. de Vries, J. Fenhann, S. Gaffin, K. Gregory, A. Grubler, T.Y. Jung, T. Kram, E.L. La Rovere, L. Michaelis, S. Mori, T. Morita, W. Papper, H. Pitcher, L. Price, K. Riahi, A. Roehrl, H.-H. Rogner, A. Sankovski, M. Schlesinger, P. Shukla, S. Smith, R. Swart, S. van Rooijen, N. Victor, Z. Dadi, Special Report on Emissions Scenarios, Intergovernmental Panel on Climate Change, Cambridge University Press, Cambridge, 2000.

[22] V. Hansen, Nye danske biller 1964 (Coleoptera) (New Danish beetles (Coleoptera)) [In Danish], Entomol. Meddr. 34 (1965) 123-124.

[23] M. Hämäläinen, Attagenus smirnovi Zhantiev (Dermestidae), uusi asuntotuholainen Soumessa. (A new indoor pest in Finland) [In Finnish], Not. Entomol 60 (1980) 230.

[24] P.S. Ottesen, Attagenus smirnovi Zhantiev (Col., Dermestidae) new to Norway a coming insect pest? Fauna Norv. Ser. B 32 (1985) 108-109.

[25] M. Černý, Faunistic records from Chechoslovakia, Attagenus smirnovi, Acta Entomol. Bohemoslov. 86 (1989) 76.

[26] E. Naumann, Faunistische Notizen. 268. Attagenus smirnovi - eine neue Art fur die DDR? (A new species for DDR?) [In German], Entomol. Nachr. Ber. 30 (1986) 270.

[27] A. Barševskis, New and rare species of beetles (Insecta: Coleoptera) in the Baltic states and Belarus, Baltic J. Coleopterol. 1 (2001) 3-18.

[28] H. Bruge, Attagenus smirnovi Zhantiev, 1973 (Coleoptera: Dermestidae) B. sp.n. avec information originale sur le mode de nutrition des adultes (Attagenus smirnovi Zhantiev, 1973 (Coleoptera: Dermestidae) B. sp.n. with original information on adult nutrition) [In French], Bulletin de la Societe Royale Belge d'Entomologie 144 (2008) 29-34.

[29] A. Pütz, Attagenus smirnovi Zhantiev, 1973 - der zweite Fund für Deutschland (Coleoptera, Dermestidae) (Attagenus smirnovi Zhantiev, 1973 - the second catch for Germany) [In German], Entomol. Nachr. Ber 36 (1992) 140-141. 